\title{
R\&D Collaboration and Global Strategy in High-tech SMEs
}

\author{
Rara Hyeseong Jeon ${ }^{1,2}$ \\ ${ }^{1}$ California State University, Dominguez Hills, USA \\ ${ }^{2}$ Global Business Consulting Firm, Y\&PEOPLE, USA
}

Copyright $\bigcirc 2018$ by authors, all rights reserved. Authors agree that this article remains permanently open access under the terms of the Creative Commons Attribution License 4.0 International License

\begin{abstract}
This paper explores which mechanism is involved between firms' global strategy and R\&D collaboration mode. Innovation is originally linked to the role of R\&D which is the most significant strategy in technological companies (Yip, 1989; Conte \& Vivarelli, 2014). To penetrate global markets, firms, especially SMEs, select local partners for R\&D to minimize risks and save cost, whereas few firms choose global partners. It would be easy if we could collaborate with partners abroad who are in the target market and understand their market needs. However, global partnership is challenging for SMEs due to the lack of networks, lack of top level human resources, lack of budget, and lack of experience. There are certain criteria involved when firms select partners or conduct inhouse $R \& D$. To examine the criteria, we select high-tech firms who export and collaborate R\&D with local and/or global partners. The purpose of our study is to encourage SMEs to achieve globalization and benefit from collaboration with local and/or global partners. The impact of collaborative innovation on SMEs and how it influences globalization is valuable to examine. We used the Upsala model for understanding the steps of globalization, and 'Global Strategy' theory (Laanti, Gabrielsson, \& Gabrielsson, 2007) to analyze case firms' global strategies. Our study explores this phenomenon for the first time: How do SMEs leverage globalization successfully through different types of $R \& D$ partners? At the end of our study, we recommend an appropriate collaboration mode for each case firm based on the firm's circumstances and the decision of globalization strategy.
\end{abstract}

Keywords Innovation (Open Innovation), Research \& Development (R\&D), Collaboration, Small Medium Sized Enterprises (SMEs), Global Strategy

\section{Introduction}

Innovation is essential for an organization's growth
(Horibe, 2003) to sustain competitive positioning and to strengthen it (Baregheh, Rowley, \& Sambrook, 2009;). At the same time, businesses are forced to find partners to benefit from innovation given rapidly changing global market conditions and increased competition (Vapola, 2011). Thus, the openness in the innovation process is becoming more prominent recently as evidenced in various academic literature (Patra \& Krishna, 2015).

Intense competition in domestic markets give a reason for firms to expand their technology into new markets overseas (Lee \& Jeong, 2010; Kang, 2012). However, the uncertainty in the global marketplace has caused a fundamental change in firms' innovation strategies (Lee \& Jeong, 2010; Kang, 2012). To mitigate this confusion and secure global markets, collaborative innovation has become commonplace in organizations, and needs to be studied (Zhang, 2011; Qiuyan, 2012).

Globalization could be done simply if firms collaborated with buyers and/or distributors abroad regardless of their size (Kang, 2012). Furthermore, different modes of network relationships have different effects on their performance (Lin \& Lin, 2016). International collaboration raises important questions regarding the relationship between R\&D and innovation (Ebersberger \& Herstad, 2013). Specifically, this study will analyze how high-tech SMEs choose different R\&D collaboration modes depending on their circumstances targeting the global markets. We use multiple case analyses to answer these questions. The first part of this paper is an article based on the literature review on open innovation, $R \& D$ collaboration, SMEs, globalization, and global strategy. In the second part, we present our contributions at the managerial and theoretical levels.

At a theoretical level, this research is based on the most recent literature related to the topic. The recent studies typically use patent data to analyze the impact of foreign knowledge sources on firms' innovations (Peters \& Schmiele, 2010), and R\&D collaboration with universities, competitors, etc.

In order to explore the phenomenon related to the topic, 
we divided partnership structures into three scenarios: "Closed", "Open \& Local", and "Open \& Global". There are potentially great advantages associated with forming global partnerships including expanding markets, improving quality, and enhancing competitiveness (MIT Sloan Management Review, 1989; Pla-Barber and Alegre, 2007; Chetty, Sylvie K., and Stangl, 2010). The firm's benefit might differ depending on its strategies and situations. However, there are no solid case studies and frameworks for high-tech SMEs to benchmark.

\section{Materials and Methods}

\subsection{Innovation and Technological Innovation}

Innovation is widely considered to play a central role in creating value, sustaining competitive advantage, and representing the evolution of any organization (Baregheh et al., 2009). Firms should actively adopt new technology and create competitiveness for long-term success. Especially, High-tech and rapidly-changing industries require huge amounts of R\&D investment and are associated with high risks (Kaufmann, Franz, 2002; Miotti and Sachwald, 2003).

This study focuses on technological innovation, which is critical to globalization (Abdullah and Zain, 2011; Verweij, Pearl, Shelton, Jasmin, Eckert, Parsons, Goddard, Seabrooke-spencer, \& White, 2012). Porter (1985), Kang (2012), and various scholars have highlighted that the key success factors for technological innovation are capabilities and management skills. Profiting from technology is imperative and it relates to the management of innovation processes (Rodríguez, Lorenzo, 2011). This research will explore how and what motivates high-tech SMEs to collaborate with partners and globalize.

Understanding the process of innovation allows firms to achieve greater efficiency in production and quality (Schumpeter, 1934; Clark and Fujimoto, 1991; Stadler, 2011; Un \& Asakawa, 2015).

\subsection{Open Innovation and Collaboration R\&D}

Opening up innovative activity involves substantial business risks with firms accidentally disclosing patented information rendering their competitive advantage obsolete (Henkel, 2006; West, 2003; Alexy et al., 2016). However, short technology life cycles, emerging technologies, rising costs, and risks associated with technological innovation provokes one to explore external partnership (Rigby and Zook, 2002; Christensen et al., 2005; Henkel, Laursen, and Salter, 2006; Enkel, Gassmann, \& Chesbrough, 2009; Lee, Park, Yoon, and Park 2010; Vanhaverbeke, 2011; Vrgov, Petar, Vidiki, Predrag, Glassman, and Brian, 2012; Kaisa, 2013), such as open innovation concept. Open innovation has been highlighted as a flow of innovation source, which is obtaining ideas or knowledge externally (Salampasis,
2015), while normal innovation focuses on the process. Open innovation stimulates the increase of diversity of technology and minimizes gaps between technological innovation and consumer needs (Greenstein, 1996; Lichtenthaler, 2011).

Firms, especially SMEs, tend to be reluctant to innovate by themselves due to the lack of resources, so they need external partners to conduct $R \& D$ and commercialize their product or technology (Wynarczyk, Pooran, 2013). SMEs can benefit from co-investment, or co-marketing, or coR\&D (Diez, 2000; Chesbrough, 2002; Vrgovic, Petar, Vidiki, Predrag, Glassman, Lee \& Jeong, 2010; Kang, 2012). However, most Korean SMEs collaborate with their partners at a later stage, such as the marketing and commercialization stage rather than the R\&D phase. The author believes that firms are able to launch their product and services overseas through the research and development activities. This is why this study is valuable to explore this new phenomenon, which is the process of R\&D collaboration.

This study divides into two criteria of collaboration based on Openness (Open/ Closed) and geography (Local/ Global) to categorize open innovation. Integrating both concepts of "Open \& Global", which is collaborating with global partners overseas, is an interesting concept to analyze whether or not these collaboration modes can benefit firms for successful globalization (Enkel, Gassmann, and Chesbrough, 2009). In this respect, the author focuses on collaboration mode for R\&D, and the strategies on what types of criteria are necessary for firms to determine collaboration modes, either local or global partnership, as a means to overcome resource constraints and optimize innovation globally. However, firms need to be careful in selecting partners, since not all collaborations are equally beneficial (Un \& Asakawa, 2015).

\subsection{Globalization and Global Strategy}

SMEs are faced with increasing prices and technological competition from large firms in their local markets (Rammer, Christian, Schmiele, Anja, 2009). This encourages SMEs to challenge and penetrate foreign markets. Globalization tends to benefit large firms compared to SMEs because scaled advantages allow large firms to create new opportunities (Rammer, Christian, Schmiele, Anja, 2009). However, difficulties and uncertainties in foreign markets lead firms to hesitate to penetrate global markets (Cooper, Edgett, and Kleinschmidt 2003; Koufteros, Vonderembse, and Jayaram 2005; Griffiths-Hemans and Grover 2006). Nevertheless, the desire to increase profits is the major reason that firms move into the global markets (Abdullah and Zain, 2011).

Trade openness is an all-encompassing concept to explain a wide range of activities such as international trade (import \& export), foreign direct investment (FDI), and cultural exchange (Archibugi \& Iammarino, 2002). Among 
definitions of globalization, the 'export' is an accurate method for SMEs to measure globalization rather than using culture, people, technology, and other traits (Chiao et. al. 2006).

In terms of global strategy, Porter (1991) and Wasniewski (2010) maintains a successful innovation strategy which involves integrating R\&D, marketing, production, and finance within a firm. These most influential factors determine the success or failure of a business and should be employed by all parts of an organization (Porter, 1991; Wasniewski, 2010), which this research analysis does through the case study.

\section{Theoretical Foundation}

\subsection{Globalization Theory- Upsala Model}

The definition of globalization is still ambiguous. The Uppsala model explains how firms gradually intensify their activities in foreign markets - it was introduced by JanJohansson and Jan-Erik Ahlen in 1977.

According to the Upsala Model, around $75 \%$ of the firms utilize "exporting" among globalization procedure, yet very few SMEs were able to open subsidiaries overseas, which is the most expensive method to globalize (Abdullah and Zain, 2011). We used "export" among globalization phase as a filter to find SMEs that qualified as our case firms.

However, several issues remain understudied, such as to show how firms leverage the export of their technology through their local or global partners in R\&D.

\subsection{Theory of Global Strategy}

According to the 'Fundamentals of global strategy' (Cornelis A. de Kluyver, 2010) is defined by adaptation, aggregation, and arbitrage (Cornelis A. de Kluyver, 2010). The article 'global strategy' demonstrates the framework of how to evaluate the globalization of individual firms based on the 'corporate strategy': market, cost, environmental, and competitive (Yip, 1989; Laanti et al., 2007). Moreover, Allaire and Firsirotu (1993) built 'Thinking strategy model', which is divided into external and internal variables (factors) and examines a firm's strategies. We integrated both strategies to explore firms' circumstances based on each category.

\section{Methodology}

We use a multiple case methodology to explore the new phenomenon: key organizational characteristics in the high-tech industry and guided future work in this area
(Cousins \& Bourgeois, 2014). Descriptive, exploratory, and explanatory analyses are essential to the case study (Cousins \& Bourgeois, 2014). Our research provides guidelines for SMEs, practitioners, government agencies, and academics. We explore the conceptual framework related to our theme. The author has chosen high-tech SMEs in South Korea involved in export. The companies exhibit one of the collaboration modes listed above. We use an allonym as a company name to secure their privacy.

To provide us with a more in-depth understanding of each SME, corporate secondary data was collected ahead of the interviews. During the research period, we were working for the case firms as a participation observation for three years. In order to compare collaboration modes, we chose SMEs that engage in successful innovation to export with global partners (Open-Global); local partners (OpenLocal); and or in-house (Closed). We conducted 24 interviews with 14 firms using different questionnaires depending on collaboration modes.

Despite the opportunity of recording each interview, notes were taken in order to collect all the information needed for this study. We applied data triangulation to check for reliability and validity, combining different qualitative methods (i.e. observations, documents, and interviews). Case firms were interviewed once or multiple times (45mins $\sim 1$ hour). We first gathered all the materials and then wrote a monograph (Eisenhardt, 1989) to synthesize all the events, giving information about the relationships between collaboration mode of R\&D and globalization.

We reviewed examined theories and research relevant themes to the current study. From participant observation, we found out the phenomenon related to our theme. The unique experiences afforded us a deep analysis of the phenomenon that may often be invisible to other researchers. From data analysis of the interviews, we translated each interview from Korean to English, and the interview transcripts were analyzed. To analyze the data gathered on the industry level, we have used coding methodologies using software. In the data, we have searched for the process of globalization through the open innovation to analyze them in depth. After the first coding, we searched for the patterns related to our themes in the data, organized the codes, and modified previous conceptual framework. We use the frequency of the codes related to our theme to explore a new phenomenon.

\section{Case Study}

Following Table 2 demonstrates a firm's global strategy. We examined three cases based on collaboration modes of R\&D: Open \& Global, Open \& Local, and Closed (inhouse). 
Table 1. Descriptive Characteristics of Case firms

\begin{tabular}{|c|c|c|c|c|c|c|c|c|c|}
\hline Firm & Position & Technology & $\begin{array}{l}\text { No. of } \\
\text { People }\end{array}$ & Revenue & $\begin{array}{c}\text { Export } \\
(\%)\end{array}$ & $\begin{array}{l}\text { R\&D } \\
\text { team }\end{array}$ & $\begin{array}{c}\text { Overseas } \\
\text { sales } \\
\text { team } \\
\end{array}$ & Subsidiary & $\begin{array}{c}\text { Types of } \\
\text { Collaboration }\end{array}$ \\
\hline \multirow{2}{*}{ YL } & \multirow{2}{*}{$\begin{array}{c}\text { CEO/ } \\
\text { Director }\end{array}$} & \multirow{2}{*}{ Security Tech. } & \multirow{2}{*}{52} & \multirow{2}{*}{$14 \mathrm{M}$} & \multirow{2}{*}{$80 \%$} & \multirow{2}{*}{$40 \%$} & \multirow{2}{*}{$20 \%$} & Distributor & \multirow{2}{*}{$\begin{array}{l}\text { Open \& } \\
\text { Global }\end{array}$} \\
\hline & & & & & & & & Overseas & \\
\hline MS & $\begin{array}{c}\text { CEO/ } \\
\text { Chief of } \\
\text { institution }\end{array}$ & $\begin{array}{l}\text { Chemicals for } \\
\text { electronics }\end{array}$ & 63 & $19 \mathrm{M}$ & $47 \%$ & $34 \%$ & $12 \%$ & $\begin{array}{c}\text { Export } \\
\text { through large } \\
\text { firms }\end{array}$ & $\begin{array}{l}\text { Open \& } \\
\text { Global }\end{array}$ \\
\hline KC & $\begin{array}{l}\text { Director/ } \\
\text { Senior } \\
\text { researcher }\end{array}$ & Semiconductor & 250 & $9 \mathrm{M}$ & $85 \%$ & $20 \%$ & $10 \%$ & Japan, China & $\begin{array}{l}\text { Open \& } \\
\text { Global }\end{array}$ \\
\hline SL & $\begin{array}{l}\text { Director/ } \\
\text { Manager }\end{array}$ & $\begin{array}{l}\text { Touch panel for } \\
\text { Smartphone }\end{array}$ & 300 & $8 \mathrm{M}$ & $87 \%$ & $11 \%$ & $5 \%$ & $\begin{array}{c}\text { China, } \\
\text { distributors in } \\
\text { Japan, USA, } \\
\text { Asia }\end{array}$ & $\begin{array}{l}\text { Open \& } \\
\text { Global }\end{array}$ \\
\hline TM & $\begin{array}{c}\text { Chairman/ } \\
\text { CEO/ Director }\end{array}$ & VR/ CCTV & 210 & $36 \mathrm{M}$ & $60 \%$ & $28 \%$ & $4 \%$ & $\begin{array}{c}\text { China, USA, } \\
\text { Europe }\end{array}$ & $\begin{array}{c}\text { Open \& } \\
\text { Global }\end{array}$ \\
\hline NT & $\begin{array}{c}\text { Head of } \\
\text { research } \\
\text { center/Director }\end{array}$ & Set-top box & 82 & $15 \mathrm{M}$ & $100 \%$ & $80 \%$ & $15 \%$ & $\begin{array}{l}\text { Distributors } \\
\text { UK, the } \\
\text { middle East, } \\
\text { S. America }\end{array}$ & $\begin{array}{l}\text { Open \& } \\
\text { Global }\end{array}$ \\
\hline AO & Director & $\begin{array}{l}\text { Medical } \\
\text { devices }\end{array}$ & 282 & $90 \mathrm{M}$ & $45 \%$ & $15 \%$ & $20 \%$ & $\begin{array}{l}\text { USA, China, } \\
\text { Japan, etc. }\end{array}$ & Open \& Local \\
\hline $\mathbf{A C}$ & $\begin{array}{l}\text { CEO/ } \\
\text { Director }\end{array}$ & $\mathrm{AR} / \mathrm{VR}$ & 51 & $9 \mathrm{M}$ & $20 \%$ & $85 \%$ & $10 \%$ & $\begin{array}{c}\text { Export } \\
\text { through large } \\
\text { firms } \\
\end{array}$ & Open \& Local \\
\hline ST & $\begin{array}{l}\text { Director/ } \\
\text { Manager }\end{array}$ & Set-top box & 42 & $3 \mathrm{M}$ & $100 \%$ & $60 \%$ & $40 \%$ & $\begin{array}{l}\text { Distributors } \\
\text { Europe, S. } \\
\text { America }\end{array}$ & Open \& Local \\
\hline OM & $\begin{array}{l}\text { Director/ } \\
\text { Head of } \\
\text { institution }\end{array}$ & $\begin{array}{l}\text { Medical } \\
\text { devices }\end{array}$ & 298 & $164 \mathrm{M}$ & $50 \%$ & $10 \%$ & $40 \%$ & China, USA & Open\& Local \\
\hline SN & Director & Crystal ceramic & 210 & $26 \mathrm{M}$ & $40 \%$ & $10 \%$ & $30 \%$ & USA, China & Closed \\
\hline ST & $\begin{array}{l}\text { Director/ } \\
\text { Manager }\end{array}$ & Protection film & 53 & $11 \mathrm{M}$ & $85 \%$ & $12 \%$ & $20 \%$ & $\begin{array}{l}\text { Distributors } \\
\text { in China, S. } \\
\text { Ease Asia, } \\
\text { Europe }\end{array}$ & Closed \\
\hline FR & $\begin{array}{c}\text { Chief of } \\
\text { institution }\end{array}$ & Robot & 52 & $4 \mathrm{M}$ & $30 \%$ & $60 \%$ & $20 \%$ & $\begin{array}{c}\text { Agent in } \\
\text { USA, China }\end{array}$ & Closed \\
\hline $\mathbf{Y N}$ & $\begin{array}{l}\text { Senior } \\
\text { researcher }\end{array}$ & $\begin{array}{l}\text { Visual art } \\
\text { equipment }\end{array}$ & 127 & $40 \mathrm{M}$ & $60 \%$ & $60 \%$ & $14 \%$ & USA, UK & Closed \\
\hline
\end{tabular}

Table 2. Corporate Strategy for Globalization: Open \& Global

\begin{tabular}{|c|c|c|}
\hline \multirow{7}{*}{$\begin{array}{l}\text { Internal } \\
\text { Strategy }\end{array}$} & $\begin{array}{c}\text { Leadership } \\
\text { (Entrepreneurship) }\end{array}$ & $\begin{array}{l}\text { The owner of firms has a strong passion about global markets, and the firms have various } \\
\text { experiences. (YL/MS/KC/SL) Firms targeted global markets from the beginning (interviews). }\end{array}$ \\
\hline & People & $\begin{array}{l}\text { Firms hired international staffs from China, Japan, etc. and they usually communicate with global } \\
\text { partners, but it's hard to find people who have engineering backgrounds and achieve language } \\
\text { proficiencies (MS/SL). The owner has international background such as study or working overseas. }\end{array}$ \\
\hline & $\begin{array}{l}\text { Technology } \\
\text { capabilities }\end{array}$ & $\begin{array}{l}\text { Firms need a more advanced level of technology to obtain comparable technologies which meet the } \\
\text { clients' needs. (YL/MS/KC) }\end{array}$ \\
\hline & Partners & Firms have global partners trust-worthy, and capable of collaborating with each other. (YL/MS) \\
\hline & Structure & Centralized: Owner of corporations build global strategies (observations/ interviews) \\
\hline & Culture & $\begin{array}{l}\text { Values: firms understand the significance of global markets, and they obtained global } \\
\text { standardization and competitive experiences overseas. (interview/observation) }\end{array}$ \\
\hline & Strategic process & The firms tend to find a market need before developing their technologies (YL/MS). \\
\hline \multirow{2}{*}{$\begin{array}{l}\text { External } \\
\text { Strategy }\end{array}$} & Product/ Service & $\begin{array}{l}\text { The firms tried to minimize the cost of product or services to compete with competitors such as } \\
\text { China and other developing countries. (YL/MS/KC) }\end{array}$ \\
\hline & Market & $\begin{array}{l}\text { The firms believe that markets are the key rather than technology. The market requires advanced } \\
\text { technology continuously. (YL/MS/SL). Technology can be sourced easily all over the world, but } \\
\text { companies cannot survive without markets (YL/MS). }\end{array}$ \\
\hline
\end{tabular}


Partnering with buyers and/or distributors abroad is the best scenario for firms to cope with the lack of technologies, lack of networks, and funds for innovation, especially targeting overseas markets. The SMEs collaborate with their buyers, distributors, or university institutions who suggest ideas and are most likely to fit on market trends. Those who collaborate with overseas partners have enough experiences such as studying or working abroad, have no language barrier, have confidence with dealing with foreign partners, and have strong passion towards global market.

Those who collaborate with local partners provide their technology to large firms are more likely to passive to penetrate overseas markets (Table3). Challenging leadership and targeting overseas markets encourage these SMEs to be independent from large firms, and create new global markets. However, uncertainty of global markets, lack of experiences overseas, a fear of failure, and lack of exemplary case studies distract a SME to build partnerships in foreign countries.

Compared to the firms that are collaborating with local and/or partners overseas, those who conduct innovation inhouse are relatively capable of developing technology with their own resources. The firms consider that their technology is the top level globally, and they are eager to protect their technology. These firms own the necessary skills to expand markets using their own channels such as agents and/or subsidiaries (Table 4).

Table 3. Corporate Strategy for Globalization: Open \& Local

\begin{tabular}{|c|c|c|}
\hline \multirow{7}{*}{$\begin{array}{l}\text { Internal } \\
\text { Strategy }\end{array}$} & $\begin{array}{c}\text { Leadership } \\
\text { (Entrepreneurship) }\end{array}$ & $\begin{array}{l}\text { "We are focusing on existing local businesses than global business to avoid risks." (AO/AC/ST) } \\
\text { They are more passive than active. (observations/ interviews) }\end{array}$ \\
\hline & People & $\begin{array}{l}\text { The owner of firms and employees have experiences overseas, but they have lack of confidence to } \\
\text { penetrate overseas market by themselves. The firms depend on their local buyers who are capable } \\
\text { multinational companies. (observations/ interviews) }\end{array}$ \\
\hline & $\begin{array}{l}\text { Technology } \\
\text { capabilities }\end{array}$ & $\begin{array}{l}\text { Those who supply their technologies to large firms are relatively advanced. They export their } \\
\text { technology through their local partners, big companies (observations/ interviews). } \\
\text { "R\&D is more intensive than marketing or any other factors since firms are relatively competitive." } \\
\text { (AC/AO/ST/OM) }\end{array}$ \\
\hline & Partners & $\begin{array}{l}\text { "We lack engineers and/or funds for R\&D encourage collaboration with local universities or } \\
\text { institutions." (AC/AC/OM). "References collaborating with conglomerates create opportunities to } \\
\text { expand our businesses." (AC/ST/OM). }\end{array}$ \\
\hline & Structure & $\begin{array}{l}\text { Centralized: Owner has a desire to secure existing businesses rather than taking the risks for global } \\
\text { markets. (observations/ interviews) }\end{array}$ \\
\hline & Culture & $\begin{array}{l}\text { Value: Regular clients (supply to large multinationals), higher level of engineers, fundraising from } \\
\text { government. (document analysis/ observations/ interviews) }\end{array}$ \\
\hline & Strategic process & $\begin{array}{l}\text { "We approach the markets as a second mover rather than first mover to minimize risks." (AC/ST) } \\
\text { The firms are satisfied to collaborate with multinational companies due to the stable income, but } \\
\text { they dissatisfied the benefit from their local client. (interview/ observation) }\end{array}$ \\
\hline \multirow{2}{*}{$\begin{array}{l}\text { External } \\
\text { Strategy }\end{array}$} & Product/service & $\begin{array}{l}\text { "We mainly focused on requirements from large firms." (AC/OM) "We need to consider cost } \\
\text { efficiencies to compete with their competitors. (AC/ST/OM) }\end{array}$ \\
\hline & Market & $\begin{array}{l}\text { "When we supply our technology to large firms, we do not need market survey." (AC/AO) } \\
\text { "Other cases, we have brainstormed with experts in either firms, universities, or institutions." } \\
\text { (AC/AO/OM) }\end{array}$ \\
\hline
\end{tabular}

Table 4. Corporate Strategy for Globalization: Closed

\begin{tabular}{|c|c|c|}
\hline \multirow{7}{*}{$\begin{array}{l}\text { Internal } \\
\text { Strategy }\end{array}$} & $\begin{array}{c}\text { Leadership } \\
\text { (Entrepreneurship) }\end{array}$ & $\begin{array}{l}\text { Firms are conservative to keep doing in-house in order to secure their technology. Immense pride of } \\
\text { their technology. Not enough experience in the global markets. (observations/interviews) }\end{array}$ \\
\hline & People & Hire individuals who have overseas experiences and networks overseas. \\
\hline & $\begin{array}{l}\text { Technology } \\
\text { capabilities }\end{array}$ & $\begin{array}{l}\text { "We are leading technology all over the world." Firms tend to collaborate with local or overseas } \\
\text { partners for the marketing and/or manufacturing who are able to develop the technology which they } \\
\text { need. (observations/ interviews) }\end{array}$ \\
\hline & Partners & $\begin{array}{l}\text { "We do not have external partners." "We do prefer to develop our technology by ourselves to secure } \\
\text { our technology." "We are afraid that our competitors emulate our technology." (SN/ST/FR) "We do } \\
\text { prefer to collaborate with partners in commercializing and/or marketing phases rather than R\&D." } \\
\text { (ST/ST/FR/YN) }\end{array}$ \\
\hline & Structure & $\begin{array}{l}\text { Centralized: Owner of firms are most likely to make a decision in terms of partnership, global } \\
\text { strategies, and technology development. (observations/ interviews) }\end{array}$ \\
\hline & Culture & $\begin{array}{l}\text { Value points: Customer focus, Intensive R\&D activities, higher level of engineers, top level of } \\
\text { technology, stable revenue from intellectual property (patent). (documents analysis/ observations/ } \\
\text { interviews) }\end{array}$ \\
\hline & Strategic process & "We focus on future technologies and business models." (SN/ST/FR) \\
\hline \multirow{2}{*}{$\begin{array}{l}\text { External } \\
\text { Strategy }\end{array}$} & Product/ service & The firms already have competitive technology and services in the world. (observations/ interviews) \\
\hline & Market & $\begin{array}{l}\text { Firms find networks and partners through government agency or participating conventions } \\
\text { (exhibitions }+ \text { conferences). (observations/ interviews) }\end{array}$ \\
\hline
\end{tabular}




\section{Theory Contribution and Discussion}

This study demonstrates recent literature related to open innovation, R\&D collaboration, and globalization. The case studies are primarily directed at high-tech SMEs in South Korea. This research provides information on what types of collaboration modes are appropriate in each firm and how high-tech SMEs implement open innovation for successful global and local collaboration (Figure 1).

This research implements collaboration theory (Wood, D. J. Gray, 1991) to show how SMEs overcome their constraints through their external partners.

The author creates a conceptual framework which other SMEs in a different industry can apply to their firms and achieve firm's globalization (Figure 1).
The firms which lack of market, technology, and budget tend to look for their partners to compensate their weakness. SMEs select their partners either global or local depending on the firm's culture, structure, market needs, leader's passion for global market, and their global experiences. To implement co-R\&D, most SMEs utilize government fund which is crucial and motivate firms to conduct R\&D with their partners. Once they complete R\&D with their partners, the firms are more likely to export their technology or services.

Following Figure 2 is the outcome of case studies based on different collaboration mode of R\&D. We answer what factors generate firms' decision of R\&D collaboration mode.

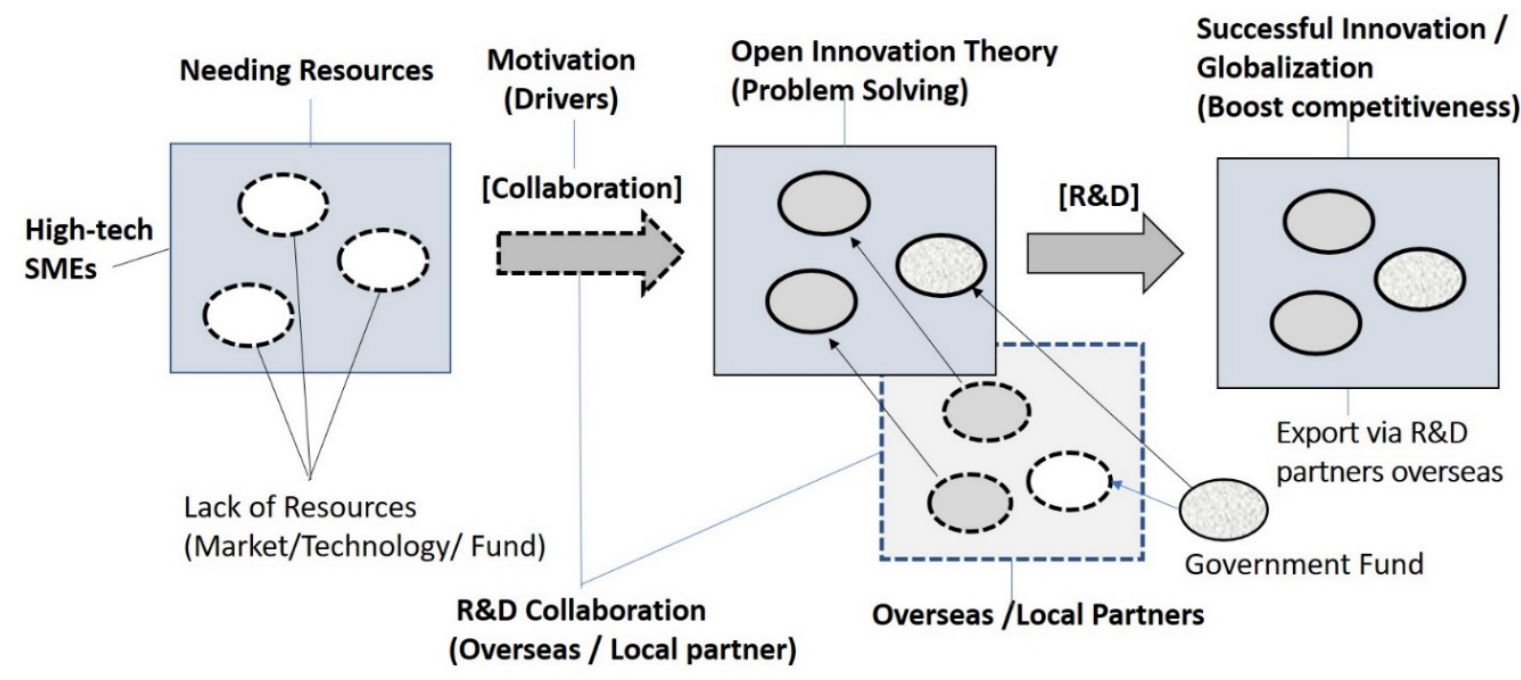

Figure 1. Conceptual Framework: The Process of Collaboration and Globalization]

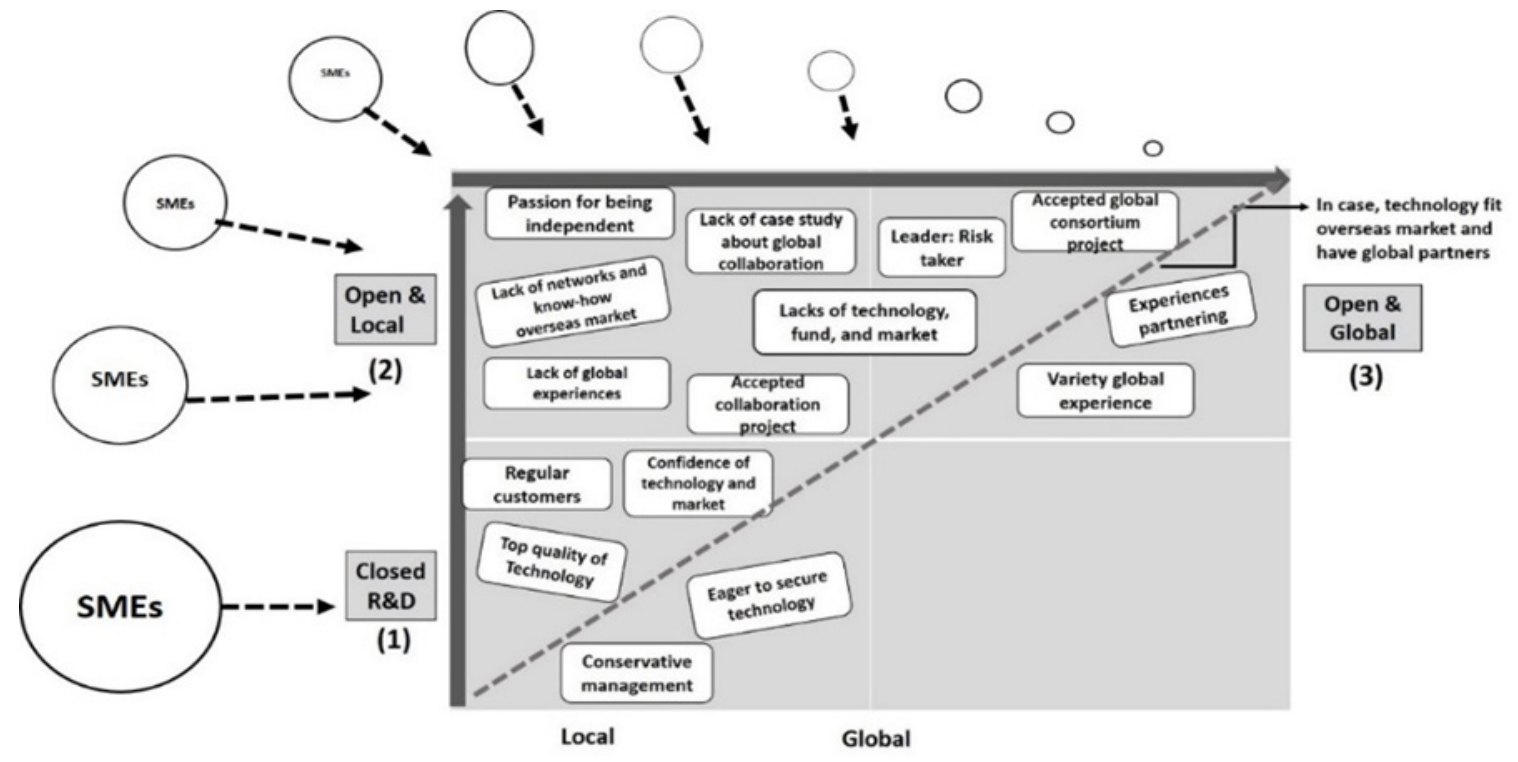

Figure 2. Drivers of R\&D Collaboration Mode: Open\& Local / Open \& Global 
Figure 2 represents the phenomenon of each type of $\mathrm{R} \& \mathrm{D}$, which are closed, open \& local, and open \& global, and demonstrates what types of SMEs select among open \& local, open \& global or closed R\&D. The circle objects (SMEs) represent the number of declining SMEs who engage in increasingly external interactions. The dotted arrow signifies firms who have the appropriate technology targeting global markets from the beginning.

Most case firms who implement Open \& Local, are eager to conduct Open \& Global after they achieve innovation with local partners. However, "there is no solid case study that SMEs can benchmark know-how implementing open innovation with global partners successfully (AC/ ST)". This is why our case study is valuable and beneficial to benchmark. Above Figure 2 are our recommendations and suggestions for beneficiaries on how firms should select collaboration modes to fit their situations to maximize benefits and mitigate risks. Depending on their circumstances and firms' decision of global strategies, firms can select one or several collaboration modes which are the most appropriate for their goals. We suggest opposite ideas for SMEs and encourage them to benchmark collaboration modes to benefit from partnerships.

\section{Discussion and Conclusions}

Each firm's strategy has been analyzed from theoretical and empirical points of view in order to explore the phenomenon what types of SMEs select either their local or global partners and how SMEs successfully collaborate with them. The outcome shows us that most SMEs conduct R\&D by themselves (in-house) rather than collaborating with external partners to protect their technologies and mitigate risks from partnerships. Compared to large firms, most SMEs collaborate with their partners at the later stage (marketing and commercialization) rather than early stage (R\&D). It might be easier for firms to find partners at a later stage, or the firms believe that $R \& D$ collaboration is not as important as later stage.

The case firms which collaborate with their local partners is due to the lack of networks, lack of confidence, lack of experience, and lack of human resources who are able to deal with foreign partners. Only those who are familiar with international market, have experience and networks abroad work together with their foreign partners for R\&D. Also, these firms find their partners through the business matching event organized by government agencies, and they utilize government subsidies for co$R \& D$ with their international partners. Once the firms collaborate with their foreign partners, they are more likely to export their technology or services to global market.

SMEs should aware that they need external partners to cope with their drawbacks, lack of resources and experience. The case firms benefit from partnership, either with local or global partners, unless they have the top level technology and/or enough budget for conducting R\&D. However, once companies fail in a collaboration with a partnership, it impacts the decision to avoid collaboration with others.

To increase the success rate of collaboration with the overseas partners, firms need to cooperate in the same space until the project is finalized such as a joint-lab. This is the best way to minimize risks caused by global partnership and to build a mutual and real-time communication. Otherwise, the time to market will most likely be delayed due to the time difference and lack of communication. Furthermore, to increase the benefit of collaboration, firms should find partners that are in the same industries and have different capabilities.

This analysis is not to evaluate which collaboration mode has more advantages than others, instead, this research recommends what types of SMEs are appropriate to collaborate, either with local or global partners. Firms choose different collaboration modes or innovating by themselves based on their circumstances, wills, and goals because the measurement of success of globalization is difficult in a timeline. Once firms benefit from their local partners, they are willing to collaborate with foreign partners overseas, too.

This research will implicate SMEs, academic institutions, practitioners, entrepreneurs, and policy makers. This analysis encourages all of academics, practitioners, and consultant to understand how SMEs utilize R\&D partners for their successful export based on their circumstances. Additionally, these findings will apply to the SMEs in a variety of industrial categories and countries.

This research has concluded that most of the decisionmaking (such as innovative strategy, the selection of R\&D partners, and global strategies) originates from owners of the companies. Thus, an enthusiastic and innovative mindset of the leaders and their international experiences are essential for successful collaboration.

Lastly, to increase the successful rate of collaboration among external partners, both parties need to break down strengths and competitive barriers and create a mutually beneficial relationship. As for the future study, we could examine how different phases of collaboration (between R\&D and commercialization phase) influence a degree of globalization, and how government policy impact firms' decision of collaboration modes. Another study could be how government policies and subsid programs influence firm's decision of collaboration mode for innovation.

\section{REFERENCE}

[1] Allaire, Y., \& Firsirotu, M. E. (1984). Theories of Organizational Culture. Organization Studies. https://doi.org/10.1177/017084068400500301

[2] Archibugi, D., \& Iammarino, S. (2002). The globalization of 
technological innovation: definition and evidence. Review of International Political Economy, 9(1), 98-122. https://doi.org/10.1080/09692290110101126

[3] Baregheh, A., Rowley, J., \& Sambrook, S. (2009). Towards a multidisciplinary definition of innovation. Management Decision, 47(8), 1323-1339. https://doi.org/10.1108/00251 740910984578

[4] Bok, Lee, Choi, and K. (2012). Open \& Global R \& D case analysis in S. Korea. SERI.

[5] Bougrain, F., \& Haudeville, B. (2002). Innovation, Collaboration and SMEs Internai Research Capacities. Research Policy, 31(5), 735-747. https://doi.org/10.1016/S 0048-7333(01)00144-5

[6] Buganza, T., \& Verganti, R. (2009). Open innovation process to inbound knowledge: Collaboration with universities in four leading firms. European Journal of Innovation Management, 12(3), 306-325. https://doi.org/10 $.1108 / 14601060910974200$

[7] Burke, G. I., \& Jarratt, D. G. (2004). The influence of information and advice on competitive strategy definition in small- and medium-sized enterprises. Qualitative Market Research: An International Journal, 7(2), 126-138. https://doi.org/10.1108/13522750410530039

[8] Chesbrough, H. (2003). Book_Open Innovation.pdf. Havard Business Review.

[9] Conte, A., \& Vivarelli, M. (2014). Succeeding in innovation: key insights on the role of $\mathrm{R} \& \mathrm{D}$ and technological acquisition drawn from company data. Empirical Economics, 47(4), 1317-1340. https://doi.org/10.1007/s00181-013$0779-1$

[10] Ebersberger, B., \& Herstad, S. J. (2013). The relationship between international innovation collaboration, intramural R\&D and SMEs' innovation performance: a quantile regression approach. Applied Economics Letters, 20(7), 626-630. https://doi.org/10.1080/13504851.2012.724158

[11] Eisenhardt, K. M. (1989). Building theories from case study research. Academy of Management Review, 14(4), 532-550.

[12] Enkel, E., Gassmann, O., \& Chesbrough, H. (2009). Open $\mathrm{R} \& \mathrm{D}$ and open innovation: exploring the phenomenon. $R \& D$ Management, 39(4), 311-316. https://doi.org/10.1111 /j.1467-9310.2009.00570.x

[13] Henttonen, K. (2013). Open innovation in SMEs collaboration modes and strategies in commercialisation phase Kaisa Henttonen *. ISPIM Conference-Innovating in Global Market, (June).

[14] Horibe, F. (2003). Innovation, Creativity, and Improvement: WORKING THE RIGHT LEVER TO PROSPERITY. The Canadian Manager, 28(1), 20-20: Page count =3. Retrieved fromhttp://search.proquest.com/docview/213665635?accou ntid=15297\%5Cnhttp://sfx.cbuc.cat/uji?url_ver=Z39.882004\&rft val fmt=info:ofi/fmt:kev:mtx:journal\&genre=un known\&sid=-ProQ:ProQ\%3Aabiglobal\&atitle=Innovation $\%$ $2 \mathrm{C}+$ Creativity $\% 2 \mathrm{C}+$ and + Improvement $\% 3 \mathrm{~A}+$ WORKING + THE+RI

[15] Huysmans, J. (2009). Introduction to the Forum on Global Society " Globalization Theory ." Forum American Bar Association, 3(1), 2009-2009.
[16] Johnson, J. H., Arya, B., \& Mirchandani, D. a. (2013). Global integration strategies of small and medium multinationals: Evidence from Taiwan. Journal of World Business, 48(1), 47-57. https://doi.org/10.1016/j.jwb.2012. 06.006

[17] Kaufmann, A., \& Tödtling, F. (2002). How effective is innovation support for SMEs? An analysis of the region of Upper Austria. Technovation, 22(3), 147-159. https://doi.org/10.1016/S0166-4972(00)00081-X

[18] Laanti, R., Gabrielsson, M., \& Gabrielsson, P. (2007). The globalization strategies of business-to-business born global firms in the wireless technology industry. Industrial Marketing Management, 36(8), 1104-1117. https://doi.org/10.1016/j.indmarman.2006.10.003

[19] Lichtenthaler, U. (2011). Open Innovation: Past Research, Current Debates, and Future Directions. Academy of Management Perspectives, 25(1), 75-93. https://doi.org/10. 5465/AMP.2011.59198451

[20] Lin, F. J., \& Lin, Y. H. (2016). The effect of network relationship on the performance of SMEs. Journal of Business Research, 69(5), 1780-1784. https://doi.org/10.10 16/j.jbusres.2015.10.055

[21] Meissner, D. (n.d.). "Globalization and Open Innovation" Implications for Innovation and Technology Policy. Swiss Science and Technology Council.

[22] Narula, R. (2004). R\&D collaboration by SMEs: new opportunities and limitations in the face of globalisation. Technovation, 24(2), 153-161. https://doi.org/10.1016/S01 66-4972(02)00045-7

[23] Network, R. S. (2014). Performance Management Collecting and Using Data to Measure Progress, Improve Results. U.S. Department of Education, (February).

[24] Nik Ab Halim, N. A., \& Zain, M. S. N. (2011). The Internationalization Theory and Malaysian Small Medium Enterprises ( SMEs ). International Journal of Trade, Economics and Finance, 2(4), 318-322.

[25] Parsons, E., Goddard, E., Seabrooke-spencer, D. J., \& White, L. (2012). The Case for a Systems Approach to Manage Technological Innovation. XXIII ISPIM Conference - Action for Innovation: Innovation from Experience, (June).

[26] Patra, S. K., \& Krishna, V. V. (2015). Globalization of R\&amp;D and open innovation: linkages of foreign R\&amp;D centers in India. Journal of Open Innovation: Technology, Market, and Complexity, 1(1), 7. https://doi.org/10.1186/s40852-015-0008-6

[27] Peters, B., \& Schmiele, A. (2010). The influence of international dispersed vs. home-based R\&D on innovation performance. Centre for European Economic Research.

[28] Petraite, M. (2013). R \& D innovation through networks and collaboration: linking innovation capabilities globally, (June).

[29] Rhee, J., Park, T., \& Lee, D. H. (2010). Drivers of innovativeness and performance for innovative SMEs in South Korea: Mediation of learning orientation. Technovation, 30(1), 65-75. https://doi.org/10.1016/j.techn ovation.2009.04.008

[30] Schneckenberg, D., Velamuri, V. K., Comberg, C., \& Spieth, 
P. (2015). Business model innovation and decision-making: Uncovering mechanisms for coping with uncertainty Business model innovation and decision-making: Uncovering mechanisms for coping with uncertainty. $R \& D$ Management, (November), 1-35. https://doi.org/10.1111/ra dm. 12205

[31] Su, Y. S., Tsang, E. W. K., \& Peng, M. W. (2009). How do internal capabilities and external partnerships affect innovativeness? Asia Pacific Journal of Management, 26(2), 309-331. https://doi.org/10.1007/s10490-008-9114-3

[32] Sung-Wook, K. (2012). An Identification of Unsuccessful, Failure Factors of Technology Innovation and Development in SMEs: A Case Study of Components and Material Industry. International Journal of Business and Management, 7(19), 16. https://doi.org/10.5539/ijbm.v7n19 p16

[33] Thorgren, S., Wincent, J., Örtqvist, D., Thomas, N., Network, R. S., Meissner, D., ... Daly, H. E. (2012). How to Drive Innovation and Business Growth: Leveraging Emerging
Technology for Sustainable Growth. Technovation, 31(1) 1-10. https://doi.org/10.5465/AMP.2011.59198451

[34] Un, C. A., \& Asakawa, K. (2015). Types of R\&D collaborations and process innovation: The benefit of collaborating upstream in the knowledge chain. Journal of Product Innovation Management, 32(1), 138-153. https://doi.org/10.1111/jpim.12229

[35] Wasniewski, K. (2010). Corporate strategies - the institutional approach. Journal of Advanced Research in Management, (10595).

[36] Wikhamn, W., \& Styhre, A. (2016). Open innovation in SMEs : a study of the Swedish bio-pharmaceutical industry. Journal of Small Business and Enterprreneurship, 28(2).

[37] Wynarczyk, P., Piperopoulos, P., \& McAdam, M. (2013). Open innovation in small and medium-sized enterprises: An overview. International Small Business Journal, 31(3), 240 255. https://doi.org/10.1177/0266242612472214 